\title{
Seasonality of prescribed fire weather windows and predicted fire behavior in the northern Great Plains, USA
}

\author{
Kathryn A. Yurkonis ${ }^{1 *}$ D, Josie Dillon', Devan A. McGranahan², David Toledo ${ }^{3}$ and Brett J. Goodwin ${ }^{1,4}$
}

\begin{abstract}
Background: Prescribed fire is an important management practice used to control woody encroachment and invasive species in grasslands. To use this practice successfully, managers must understand the seasonal windows within which prescribed fire can be applied and how fire behavior could potentially vary among these windows. To characterize prescribed fire windows within the northern Great Plains of North America, we collected data from 20 remote weather stations positioned across North Dakota and northwestern Minnesota, USA, from station inception to 2015. We performed an hourly analysis for each station to determine if air temperature $\left(2\right.$ to $43{ }^{\circ} \mathrm{C}$ ), relative humidity (25 to $\left.80 \%\right)$, and wind speed (6.44 to $24.12 \mathrm{~km} \mathrm{~h}^{-1}$ ) conditions were within acceptable ranges for at least six contiguous precipitation-free hours from 0800 to $1800 \mathrm{~h}$. We summarized acceptable conditions over five half-season windows and then used the Rothermel fire spread equation to simulate fire behavior within these half-season windows based on average, minimum, and maximum conditions for seasonally appropriate live herbaceous to fine dead fuel ratios.
\end{abstract}

Results: While the number of acceptable prescribed fire days did not change from early spring (21 March) to early fall (6 November), the number of acceptable days for conducting spring fires decreased and the number of acceptable days for conducting late summer to early fall fires increased over the study period. The change in spring acceptability reflected an increase in the number of days with air temperatures below acceptable minimum temperature and outside of acceptable wind conditions to conduct operations. Predicted rate of fire spread was highest and most sensitive to the season of the year, fuel curing status, and site invasion status when fire spread was simulated at the upper end of acceptable wind speed and at the lower end of fuel moisture conditions.

Conclusions: Prescribed fire planning needs to take into account the timeframe during which fire windows exist within a year, and how these conditions affect fire behavior. In the northern Great Plains, there is ample opportunity for grassland managers to use summer and fall prescribed fires, and managers should expect to get variable fire behavior results when prescribed fires are applied in more extreme conditions throughout the year.

Keywords: climate change, fire behavior, fire rate of spread, fire weather, grassland adaptive management, mixed grass prairie, tallgrass prairie

\footnotetext{
* Correspondence: kathryn.yurkonis@und.edu

${ }^{1}$ Department of Biology, University of North Dakota, 10 Cornell Street, Stop

9019, Grand Forks, North Dakota 58202, USA

Full list of author information is available at the end of the article
} 


\section{Resumen}

Antecedentes: La quema prescrita es una importante práctica de manejo para controlar el establecimiento de arbustos y especies invasivas en pastizales. Para usar esta práctica de manera efectiva, los gestores deben entender las variaciones estacionales en las ventanas de prescripción dentro de las cuales las quemas prescriptas pueden ser aplicadas, y cómo el comportamiento del fuego puede variar dentro de esas ventanas. Para caracterizar las ventanas de prescripción dentro de las Grandes Planicies Centrales de América del Norte, coleccionamos datos de 20 estaciones meteorológicas ubicadas a través de Dakota del Norte y el noroeste de Minnesota, EEUU, desde su instalación y hasta 2015. Realizamos un análisis horario para cada estación para determinar si las condiciones de temperatura de aire (de 2 a $43^{\circ} \mathrm{C}$ ), la humedad relativa (del 25 al 80\%), y la velocidad del viento (de 6,44 a $24,12 \mathrm{~km} \mathrm{~h}^{-1}$ ) estaban dentro de los rangos aceptables de al menos seis horas seguidas libres de precipitación desde las 0800 hasta las $1800 \mathrm{~h}$.

Resultados: Durante el periodo de estudio, el número de días aptos para realizar las quemas no cambiaron desde comienzos de la primavera (21 de marzo) hasta principios del otoño (6 de noviembre). Sin embargo, el número de días aptos para conducir quemas de primavera decreció, y el número de días aptos para hacerlas hacia finales del verano y principios de otoño se incrementó. El cambio en la capacidad de quemar durante la primavera es un reflejó de un incremento en el número de días con temperaturas del aire por debajo de límites aceptables y por fuera de condiciones de viento aceptables para conducir operaciones de quema. Predicciones de tasa de propagación fueron más altas y más sensibles cuando la estación del año, el secado de los combustibles, y el estatus de invasión fueron simulados en el extremo más alto de velocidades de vientos aceptables y en las condiciones más bajas de humedad de combustibles.

Conclusiones: La planeación de quemas prescritas necesita tener en cuenta las condiciones durante las cuales existen ventanas de prescripción dentro de un año, y como esas condiciones afectan el comportamiento del fuego. En las Grandes Planicies de América de Norte, hay una amplia oportunidad para que los encargados del manejo de pastizales puedan usar quemas prescriptas durante el verano y otoño, y deben esperar obtener resultados de comportamiento de fuego variable cuando éstas quemas son aplicadas bajo condiciones más extremas.

\section{Introduction}

Prescribed fire is important in grasslands worldwide to control woody encroachment and invasive species (Salesman and Thomsen 1993, Grace et al. 2001, Willson 2000, Grant et al. 2009, Bahm et al. 2011). Prescribed fire use is subject to management decisions based on fuel and weather conditions at the time of ignition, and it is important to determine when it is most appropriate to burn to meet conservation objectives. In the northern Great Plains of North America, burning in different seasons does little to affect grassland productivity and composition (Clarke $e t$ al. 1943, Biondini et al. 1989, Engle and Bidwell 2001, Vermeire et al. 2011, Russell et al. 2015). However, it remains unclear to what extent the opportunity to conduct prescribed fire exists in any season, and to what extent this opportunity is affected by regional climate change (Huffman 2014, Chiodi et al. 2018).

The effect of climate change on opportunities to burn is especially important to consider within the northern Great Plains of North America as this region has experienced rapid temperature changes in recent decades (Karl et al. 1996, Easterling et al. 1997, Werner et al. 2013, Shafer et al. 2014). In general, average annual air temperatures vary latitudinally in the region, and average annual precipitation varies longitudinally (Bunkers et al. 1996a, Seager et al. 2018b), resulting in a gradient between mixed grass prairies in the west and the northern extent of the tallgrass prairie region in the east (Seager et al. 2018a). Climate in the region is influenced by the El Niño and La Niña phases of the Pacific Ocean Southern Oscillation and by the Pacific Decadal Oscillation (Bunkers et al. 1996b, Ciuti et al. 2015), which have contributed to decadal cycles between drought and deluge conditions (Winter and Rosenberry 1998, Woodhouse and Overpeck 1998, Dunnell and Travers 2011). Beginning in the early 1990s, the northern plains entered an extended wet period (Winter and Rosenberry 1998, Mushet et al. 2015), interrupted by severe droughts in 2012 and 2017 (Hoerling et al. 2014, Roundy and Santanello 2017). In addition to these climate cycles, global climate models predict that substantial changes in winter air temperatures and in winter and spring precipitation will occur into the future (Kunkel et al. 2013, Melillo et al. 2014), which has been predicted to affect the gradient of vegetation types in the region (Seager et al. 2018a, b). Spring temperatures are projected to change the least, and global climate models suggest that summer and fall precipitation should remain relatively constant across the northern Great Plains (Kunkel et al. 2013, Melillo et al. 2014). Changes in air temperature and precipitation have led to longer growing seasons (Skaggs and Baker 1985, Easterling 2002, Badh et al. 2009, Dunnell and Travers 2011, Shafer et al. 2014).

As with other ecosystem responses, short- and long-term climatic changes may affect the opportunity 
for grassland managers to safely and effectively conduct prescribed burns (Brown et al. 2004, Huffman 2014, Chiodi et al. 2018). Throughout the temperate regions, the application of prescribed fire for grassland management is a seasonal event dictated by fuel and weather conditions. Weir (2011) identified when such seasonal prescribed fire windows exist in the southern plains by reviewing hourly weather data over a 13 -year period for a site in north-central Oklahoma, USA. Weir classified acceptable burn days as those for which temperature, wind, precipitation, and relative humidity conditions were within a range in which prescribed fire could realistically be applied. Although the analysis did not include a temporal component, Weir's (2011) conclusions from the southern plains suggested that more available days exist than are currently being used. Chiodi et al. (2018) conducted a similar analysis that considered the effects of climate variability on prescribed fire weather windows for the southeastern USA (including the southeastern tallgrass prairie region), but focused primarily on mixing height and transport winds. Chiodi et al. (2018) reported that, year to year variability in the seasonal prescribed fire windows over a 31-year period was associated with El Niño events, but it remains unclear whether or not there was an overall temporal component to this response. In the northern Great Plains, most prescribed fire takes place in spring (from snowmelt to after green-up) and fall (from plant senescence to snow accumulation), although ample opportunity likely exists outside of these windows during the summer months (Weir 2011). These prescribed fire windows, and even daily conditions within these windows, are likely dynamic over time, but, to our knowledge, no one has systematically assessed prescribed fire windows or temporal trends within them for the northern Great Plains.

In addition to understanding how many burn days are available per season, and how their availability has changed over time, we need to consider how fire behavior varies across seasons to predict the variability in the effectiveness of prescribed fire. Fire behavior can be affected by weather conditions at the time of ignition, weather conditions during a fire (e.g., fuel moisture, wind speed), and by conditions in the fuelbed (e.g., total fuel availability, the ratio of live to dead fuels) (Rothermel 1972, Scott and Burgan 2005). Even within a single fuel type, such as grassland, different species cure at different rates, and fire behavior can depend on the species composition of the fuelbed (McGranahan et al. 2016). This is particularly important in the Great Plains region where cool-season invasive grasses (Poa pratensis L. and Bromus inermis Leyss.) account for 10\% of the total cover for all plant species, and approximately $62 \%$ of the non-native species cover (Toledo et al. 2014). Within typical dormant seasons, increased proportions of cool-season, $\mathrm{C}_{3}$ grasses in otherwise $\mathrm{C}_{4}$-dominated grasslands can reduce the stature of the fuelbed and introduce high-moisture live fuels during the dormant period when these warm-season communities often burn. This asynchrony in fuel moisture can substantially reduce fire spread (McGranahan et al. 2012, McGranahan et al. 2013, McGranahan et al. 2018). In the northern Great Plains, we anticipate that increased abundances of cool-season invasive grasses (e.g., Poa pratensis) will modulate the effectiveness of prescribed fire within acceptable burn days at both seasonal and day-to-day scales if it contributes enough to the live fuel load to reduce fire spread.

We identified days that had weather conditions acceptable for prescribed fires within the northern Great Plains. We then determined how these windows and predicted fire behavior associated with weather conditions within these windows have changed over time. We defined acceptable burn days following Weir's (2011) criteria from the southern plains for the two USA National Weather Service Fire Weather Zones (Bismarck and Grand Forks; www.weather.gov/gis/FireZones) that encompass the northern mixed grass and tallgrass prairie regions. We sought to determine whether the seasonal distribution of acceptable burn days has shifted and, if so, whether seasonal differences in weather and fuel conditions might also contribute to seasonal differences in fire behavior. We tested the hypotheses that the prescribed fire seasons differ between the eastern and western portion of the region and that temporal effects on prescribed fire seasons and fire behavior differ between these areas. Our results inform regional prescribed fire management activities and demonstrate how weather and fuels data can be assessed in order to inform grassland adaptive management and climate change planning efforts (e.g., Grant et al. 2009, Bierbaum et al. 2013, Romsdahl et al. 2013), with regard to the use of prescribed fire.

\section{Methods}

We collected hourly weather data from Remote Automatic Weather Stations (RAWS) within the Bismarck $(n=9)$ and Grand Forks $(n=11$; Fig. 1) Fire Weather Zones from station inception to 2015 (data obtained from MesoWest: https://mesowest.utah.edu/). These stations are part of a network of weather stations specifically installed in remote areas for the purposes of providing fuels and weather data to be used in fire weather forecasting (Zachariassen et al. 2003). Complete years of RAWS data were available electronically for eight of the stations from 2003 onward, and for the remaining stations, at minimum, from 2010 onward. Each year of data was reviewed for each station. An entire year of data for a station was excluded from analysis if 14 or more days of measurements (21 instances) were missing, or if there was evidence of sustained air temperature, relative humidity, or wind sensor malfunctions during a year (20 instances). Data from the Long 


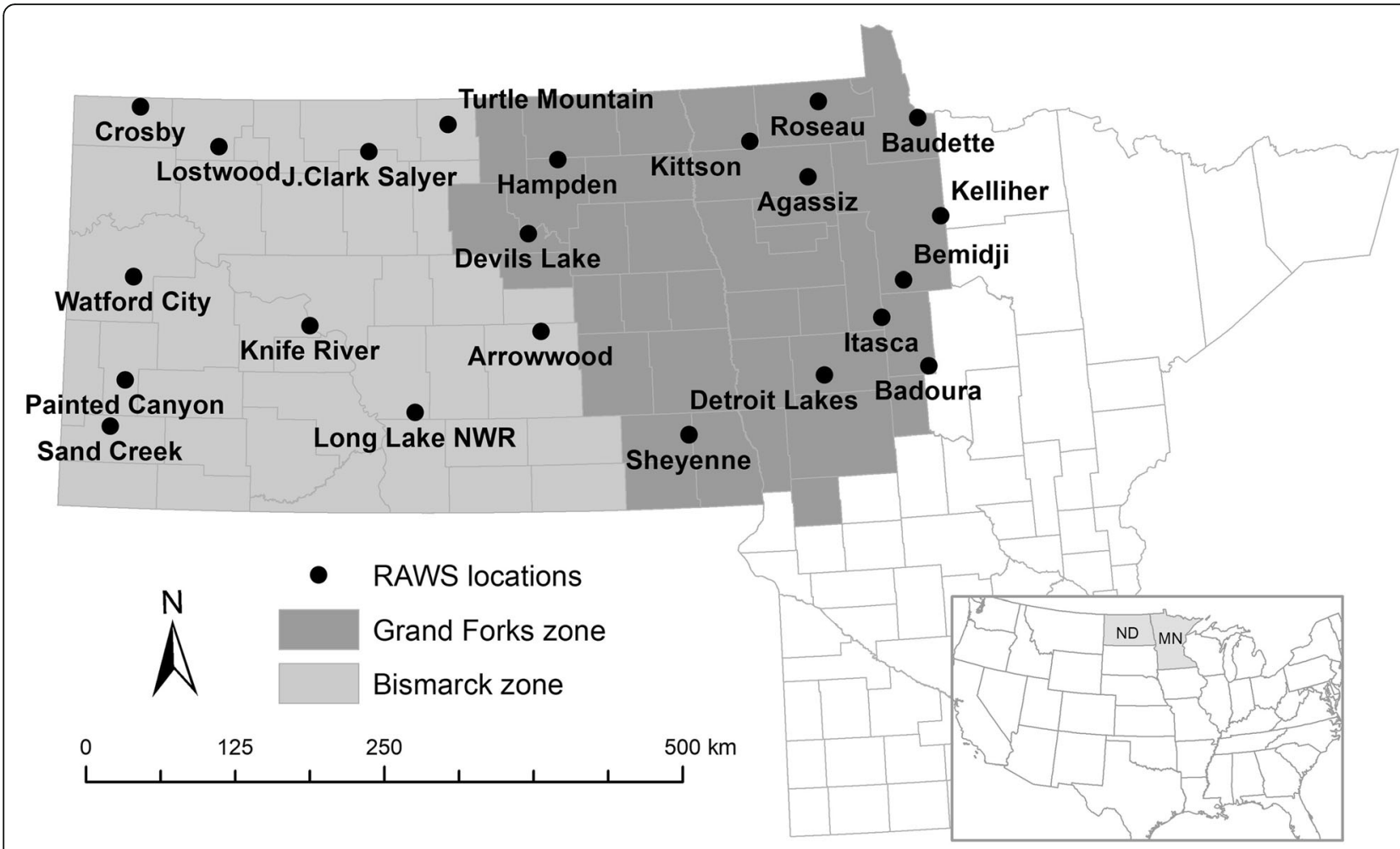

Fig. 1 Locations of the 20 Remote Automatic Weather Stations (RAWS) within the western Bismarck $(n=9)$ and eastern Grand Forks $(n=11)$ USA National Weather Service Fire Weather Zones that span North Dakota (ND) and Minnesota (MN), USA (shaded area in inset)

Lake National Wildlife Refuge (Bismarck zone) and Kittson (Grand Forks zone) stations were excluded entirely because each station had no more than three years of acceptable data. Following these reductions, we had 190 years of viable station data (reduced from 236; Bismarck $=74$ station-years, Grand Forks = 116 station-years) from across the region.

Within each year, acceptable fire weather days were identified following a protocol developed from Weir (2011). We isolated station data to a 10 -h period (800 to $1800 \mathrm{~h}$ ) and assessed days that did not have any precipitation during this period. This daily time frame represents that for which regional managers are most likely to ignite a fire on a large (64.75 ha or greater, typical unit size) parcel. We excluded late evening from our analyses, as it is currently rare that an agency would ignite a fire after $1800 \mathrm{~h}$. A day was considered acceptable if air temperatures were between $2{ }^{\circ} \mathrm{C}$ and $43{ }^{\circ} \mathrm{C}\left(35^{\circ} \mathrm{F}\right.$ and $\left.110{ }^{\circ} \mathrm{F}\right)$, relative humidity was between $25 \%$ and $80 \%$, and the sustained wind speed averaged between $6.44 \mathrm{~km} \mathrm{~h}^{-1}$ and $24.12 \mathrm{~km} \mathrm{~h}^{-1}$ (4 mph and $15 \mathrm{mph}$ ) for at least six contiguous hours during this period. A six-hour period was selected as this is a reasonable estimate of the time needed to complete prescribed fire operations on a 64.75 ha parcel based on previous prescribed fire experience in the area. On days with separated blocks of acceptable conditions, we limited our subsequent summarizations to the first acceptable period of six or more hours. Although atmospheric mixing height and transport winds, as they relate to smoke management, strongly affect application of prescribed fire elsewhere (Chiodi et al. 2018), these data were not included in our analyses as they are not readily available from RAWS and are of less importance within prescribed fire ignition plans in the relatively sparsely populated northern Great Plains.

Each astronomical season (spring, summer, and fall) was divided into two equal periods (early and late) to generate a series of six half-season periods over which we summarized the proportion of acceptable burn days (Table 1). Data from the late fall period was not assessed as the fire season typically ended early in this period and over half of the station years had fewer than five acceptable days within this 45-day period. We calculated average air temperature, relative humidity, dew point, sustained wind speed, and fine dead fuel moisture across all days from 0800 to $1800 \mathrm{~h}$ and across daily acceptable windows.

\section{Fire window analysis}

To test for geographic and temporal effects on half-season fire weather windows, zone $(\mathrm{Z})$, year $(\mathrm{Y})$, and their interactive effects on the annual number of acceptable days, 
Table 1 Live herbaceous (LH) and find dead (FD) fuel load scenarios for mixed grass prairie by half-season under two simulated cool-season grass ( $P$. pratensis) invasion scenarios. These proportions were based on fuel data collected in 2017 and 2018 from a P. pratensis-invaded grassland at the Central Grasslands Research Extension Center, Streeter, North Dakota, USA, located in the center of the northern Great Plains study area (Fig. 1). Fuel loads were calculated from these ratios based on a total of $4.4 \mathrm{t} \mathrm{ha}^{-1}$ in early spring to early summer, and $4.5 \mathrm{t} \mathrm{ha}^{-1}$ in late summer and early fall to account for growth

\begin{tabular}{lccccc}
\hline & \multicolumn{2}{c}{ Low invasion } & & \multicolumn{2}{c}{ High invasion } \\
\cline { 2 - 3 } Season & LH (\%) & FD (\%) & & LH (\%) & FD (\%) \\
\hline Early spring & 0.05 & 0.95 & & 0.10 & 0.90 \\
Late spring & 0.15 & 0.85 & & 0.25 & 0.75 \\
Early summer & 0.33 & 0.67 & & 0.50 & 0.50 \\
Late summer & 0.66 & 0.34 & & 0.70 & 0.30 \\
Early fall & 0.15 & 0.85 & & 0.33 & 0.67 \\
\hline
\end{tabular}

the proportion of acceptable days were assessed with repeated measures analysis of variance (proc mixed; SAS version 9.3; SAS Institute, Cary, North Carolina, USA). We used a random statement to account for stations nested in zones and a repeated statement to account for yearly station observations. These analyses were conducted when year was treated categorically to test for an overall year effect, and when year was treated specifically as a continuous effect to test for a linear response over time.

We used multivariate analyses to test half-season, zone, and year effects on average weather and fuel conditions during the acceptable half-season fire weather windows. We used a Principal Components Analysis to assess variation in average air temperature, relative humidity, dew point, wind speed, and fuel moisture during acceptable fire windows in each half-season using the rda function in the vegan package for the $\mathrm{R}$ statistical environment (Oksanen et al. 2017; R Core Team 2017). We fit half-season, zone, and year as factors onto the resulting ordination and tested their significance with a permutation test (999 permutations; envfit function in vegan). We stratified this permutational analysis by station to account for repeated measurements. We tested for pairwise differences among levels of the factors that were significantly $(\alpha=0.95)$ correlated with the ordination with permutational MANOVA using the pairwise.perm.manova function in the $R$ package RVAideMemoire (Hervé 2018), which includes a multiple-comparison $P$-value correction.

Because fuel moisture was not recorded consistently across all station-years, we conducted the multivariate analysis for the entire weather variable dataset (190 station-years $\times 5$ half-seasons $=950$ data rows spanning 2003 to 2015) and a reduced dataset in which entries for the four weather variables and fuel moisture were available (645 data rows spanning 2005 to 2015). The outcomes for these analyses were similar. For brevity, we present the results from the reduced dataset.

\section{Fire spread simulations}

To demonstrate how variation in acceptable fire weather conditions among half-seasons would affect fire behavior, we simulated head fire spread through northern mixedgrass prairie fuelbeds with the Rothermel (1972) fire spread equation. To achieve this, we simulated fire spread in fuelbeds with a low and high proportion of Poa pratensis under three weather and three curing scenarios in each half-season (90 simulations total) using the ros function in the Rothermel package for $\mathrm{R}$ (Vacchiano and Ascoli 2015). For all simulations, we fixed slope at $0 \%$ and total fuel load at $4.4 \mathrm{t} \mathrm{ha}^{-1}$ based on the GR4 grass fuel model (Scott and Burgan 2005) for early spring to early summer. We increased the fuel load to $4.5 \mathrm{t} \mathrm{ha}^{-1}$ in late summer and early fall to account for growing-season growth. Fuelbeds were simulated with a low or a high proportion of Poa pratensis in each half-season. Fuelbed depths were set at $60 \mathrm{~cm}$ for low $P$. pratensis fuels and reduced to $46 \mathrm{~cm}$ for high $P$. pratensis fuels across all half-season simulations to reflect the low stature of $P$. pratensis-invaded grassland. We varied the proportion of live herbaceous to fine dead fuels among half seasons in the high and low $P$. pratensis fuels (Table 1). Live fuel proportions were based on seasonal aboveground live and dead plant biomass data collected from a $P$. pratensis-invaded grassland located near the center of our geographic study area (M. Lakey, North Dakota State University, Fargo, North Dakota, USA, unpublished data). For each half-season, we calculated the range and quintiles of the proportion of plant biomass in the live component. We selected the second quintile value to represent the live fuel proportion in the low $P$. pratensis fuel and the fourth quintile value to represent the live fuel proportion in the high $P$. pratensis fuel for our simulations (Table 1). We modeled live herbaceous curing under 60\%, $90 \%$, and $120 \%$ fuel moisture scenarios.

We ran fire spread simulations under three wind speed and fine dead fuel moisture scenarios. For each half-season, we determined the minimum, maximum, and median wind speed and fuel moisture within acceptable fire weather windows across both zones and all station-years (Table 2). Because there was minimal variation across half-seasons in these variables, for simplicity we used the minimal, maximal, and median values across all half-seasons in the simulations. We used maximum wind speed $\left(22 \mathrm{~km} \mathrm{~h}^{-1}\right)$ and minimum fuel moisture (7\%) values to simulate an "upper" scenario that represented fire spread in the upper bound of acceptable fire weather conditions. We used minimum wind speed $\left(7 \mathrm{~km} \mathrm{~h}^{-1}\right)$ and maximum fine dead fuel moisture (20\%) values to simulate a "lower" scenario that represented fire spread in the lower bound of acceptable fire weather conditions. 
Table 2 Maximum, median, and minimum fuel moisture and wind speed conditions during acceptable fire windows in five half-season periods (dates listed in Table 3) from 2003 to 2015 across the Bismarck and Grand Forks fire weather zones that cover North Dakota and Minnesota, USA (Fig. 1)

\begin{tabular}{|c|c|c|c|c|c|c|}
\hline \multirow[t]{2}{*}{ Half-season } & \multicolumn{3}{|c|}{ Wind speed $\left(\mathrm{km} \mathrm{h}^{-1}\right)$} & \multicolumn{3}{|c|}{ Fuel moisture (\%) } \\
\hline & low & median & high & low & median & high \\
\hline Early spring & 7 & 14 & 22 & 8 & 11 & 20 \\
\hline Late spring & 7 & 14 & 22 & 9 & 12 & 20 \\
\hline Early summer & 7 & 14 & 18 & 7 & 11 & 18 \\
\hline Late summer & 7 & 14 & 18 & 8 & 11 & 17 \\
\hline Early fall & 7 & 14 & 18 & 9 & 12 & 19 \\
\hline
\end{tabular}

Finally, we used median wind speed $\left(14 \mathrm{~km} \mathrm{~h}^{-1}\right)$ and fuel moisture $(11 \%)$ values to simulate a "median" scenario that represented fire spread during average conditions. We averaged wind speed and fuel moisture across zones and years as fire weather conditions within the acceptable windows did not substantially vary either between fire weather zones or through time in the multivariate analyses.

\section{Results}

Annual fire weather windows differed between zones and among years; however, there was no discernible temporal effect on the total length of these windows (Table 3; year $\left.F_{1,55.5}=0.86, P>0.10\right)$. The prescribed fire weather window was $15 \%$ shorter in the western part of the study region (Bismarck zone $=102.86 \pm 5.59$ days $\mathrm{yr}^{-1}$ ) as compared to the eastern portion of the study region (Grand Forks zone $=120.82 \pm 4.81$ days $\mathrm{yr}^{-1}$ ). To visualize this zone difference in the length of the prescribed fire windows, we summarized acceptable day data in terms of what proportion of years 2003 to 2015 that a day was deemed acceptable across stations (Fig. 2). With this depiction, we showed the likelihood that conditions would be acceptable for each calendar day across the 2003 to 2015 period (Fig. 2). In the Bismarck zone, the proportion of years with acceptable conditions exceeded 20\% between 7 May and 2 November. In contrast, this period ranged between 26 March and 11 November in the Grand Forks zone. In both zones, the highest probabilities occurred from June through October. This window reflects the portion of the year during which prescribed fires could be most consistently executed among years.

In order to visualize the year effect on prescribed fire windows, we summarized acceptable day data in terms of proportion of the stations that a day was deemed acceptable in a year from early spring to late fall (Fig. 3). With this depiction, we showed to what extent conditions were acceptable across the geographic region in a given year. In both zones, variability among years was considerable, but there was a shift in this favorability from the first half (2003 to 2009) to the second half (2010 to2015) of the study period. From 2003 to 2009, stations in the western Bismarck zone more consistently experienced acceptable conditions from late June to early August. From 2010 to 2015, this period expanded to late June to early September. Likewise, from 2003 to 2009, stations in the eastern Grand Forks zone more consistently experienced acceptable conditions from June to September. From 2010 to 2015, this period expanded to late May to October. These are the periods during which prescribed fires could be executed most reliably across sites in each zone. Raw proportion data for each station-year, which serves as a basis for these figures, is shown in Additional file 1.

To quantify the temporal shifts in acceptable fire weather windows, we additionally considered favorability in each half-season window separately from the overall annual trends in fire weather windows. Within half-seasons, the proportion of acceptable days from early spring to late fall differed between zones and among years (Table 3, Fig. 4). The proportion of acceptable days in early spring declined by $10 \%$ from the first to the last three years of the study timeframe (year $F_{1,73}=18.75, P<0.0001$; zone $\left.F_{2,72.3}=11.62, P<0.0001 ; \mathrm{Z} \times \mathrm{Y} P<0.10\right)$ across both zones. This corresponds to loss of 4.5 days in the

Table $3 \mathrm{~F}$-values and degrees of freedom (df; numerator,denominator) from repeated measures analysis of variance of zone (Z), year (Y; categorical), and their interactive $(Z \times Y)$ effects on the proportion of acceptable prescribed fire days within each half-season and on the total number of acceptable days annually from 2003 to 2015 for the Bismarck and Grand Forks fire weather zones that cover North Dakota and Minnesota, USA (Fig. 1)

\begin{tabular}{|c|c|c|c|c|c|c|c|}
\hline Variable & Dates & df & Zone & $d f$ & Year & $\mathrm{df}$ & $Z \times Y$ \\
\hline Total days & & 1,19 & $5.25^{*}$ & 12,129 & $2.41^{* *}$ & 11,127 & 1.26 \\
\hline Early spring & 21 Mar to 5 May & $1,19.2$ & $6.27^{*}$ & 12,128 & $7.89^{* * *}$ & 11,127 & $2.44^{* *}$ \\
\hline Late spring & 6 May to 20 June & $1,19.2$ & $3.01^{+}$ & 12,129 & $3.20^{* * *}$ & 11,128 & $2.16^{*}$ \\
\hline Early summer & 21 Jun to 6 Aug & $1,19.1$ & $6.88^{*}$ & 12,132 & $1.70^{\dagger}$ & 11,130 & 0.75 \\
\hline Late summer & 7 Aug to 21 Sept & 1,20 & $9.29^{* *}$ & 12,131 & $4.78^{* * *}$ & 11,129 & 1.18 \\
\hline Early fall & $22 \mathrm{Sep}$ to $6 \mathrm{Nov}$ & $1,19.1$ & $3.85^{\dagger}$ & 12,128 & $9.70^{* * * *}$ & 11,126 & $2.31^{*}$ \\
\hline
\end{tabular}

${ }^{*} P<0.05$,

${ }^{* *} P<0.01$,

*** $P<0.001$,

${ }^{\dagger} P<0.10$ 


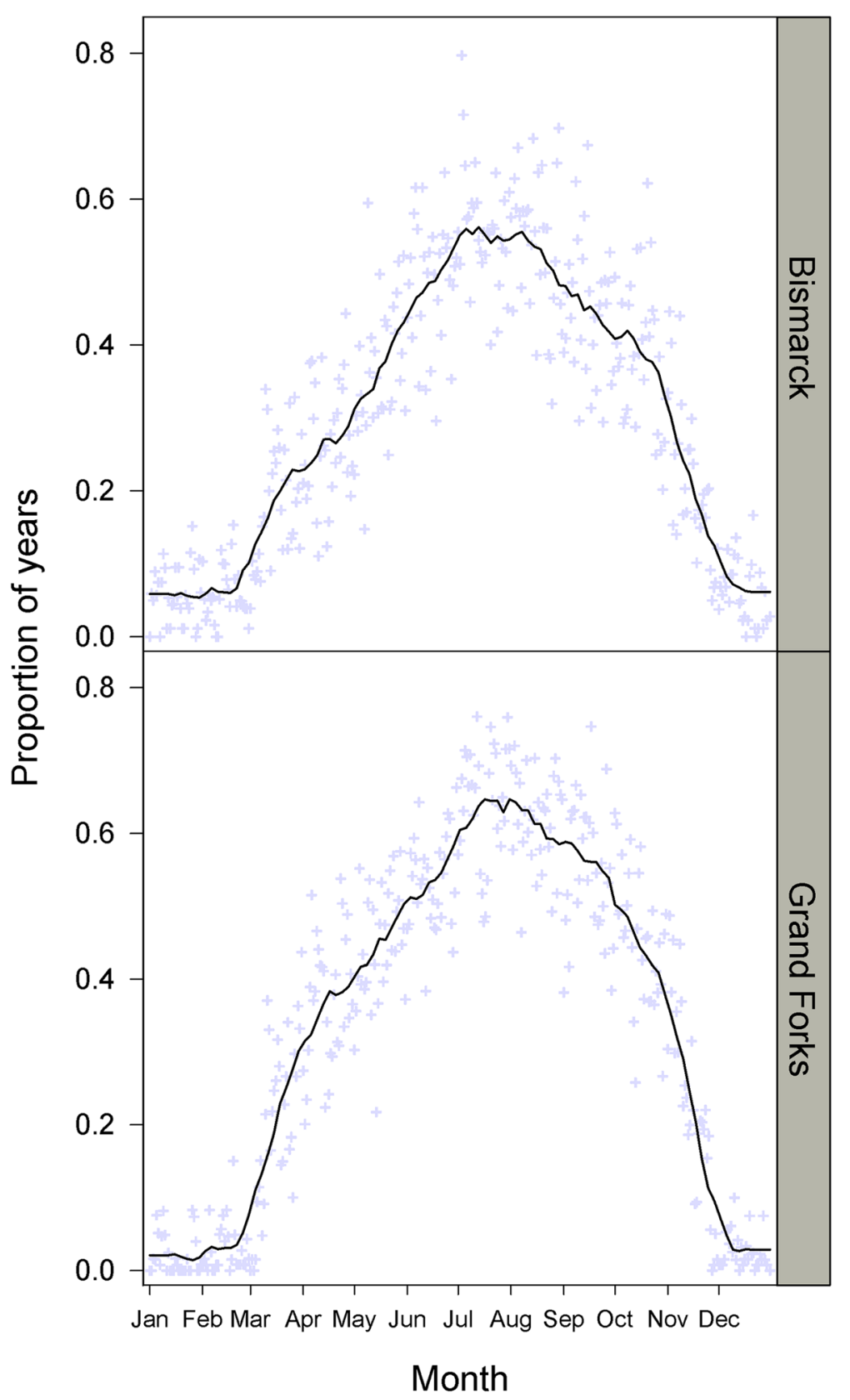

Fig. 2 Prescribed fire weather windows in the western Bismarck (top panel; $n=74$ station-years) and eastern Grand Forks (bottom panel; $n=116$ station-years) fire weather zones that cover North Dakota and Minnesota, USA (Fig. 1). Zone data are summarized for 2003 to 2015. For each day of the year, the proportion of years (averaged across all stations) for which weather conditions were acceptable for prescribed fire are graphed (points: +). See text for query parameters used to determine daily fire weather windows. Lines are smoothed averages over a running four-week period

early spring prescribed fire season. In contrast, the proportion of days marginally increased from late summer (year $F_{1,54.5}=3.13, P=0.082$; zone $P<0.10 ; \mathrm{Z} \times \mathrm{Y} P<0.10$ ) to early fall (year $F_{1,69.4}=3.11, P=0.082$; zone $P<0.10$; $\mathrm{Z} \times$ Y $P<0.10)$ across both zones (Fig. 4). This effect was more pronounced in the western Bismarck zone than in the eastern Grand Forks zone. In the Bismarck zone, the proportion of acceptable days in late summer increased by $6 \%$ ( 2.7 days) and increased by $4 \%$ (1.8 days) in early fall between the first and the last three years of the study period. In the Grand Forks zone, the proportion of acceptable days increased by $1 \%$ ( 0.5 days) in late summer and 2\% ( 0.9 days) in early fall between the first and last three years of the study period. 


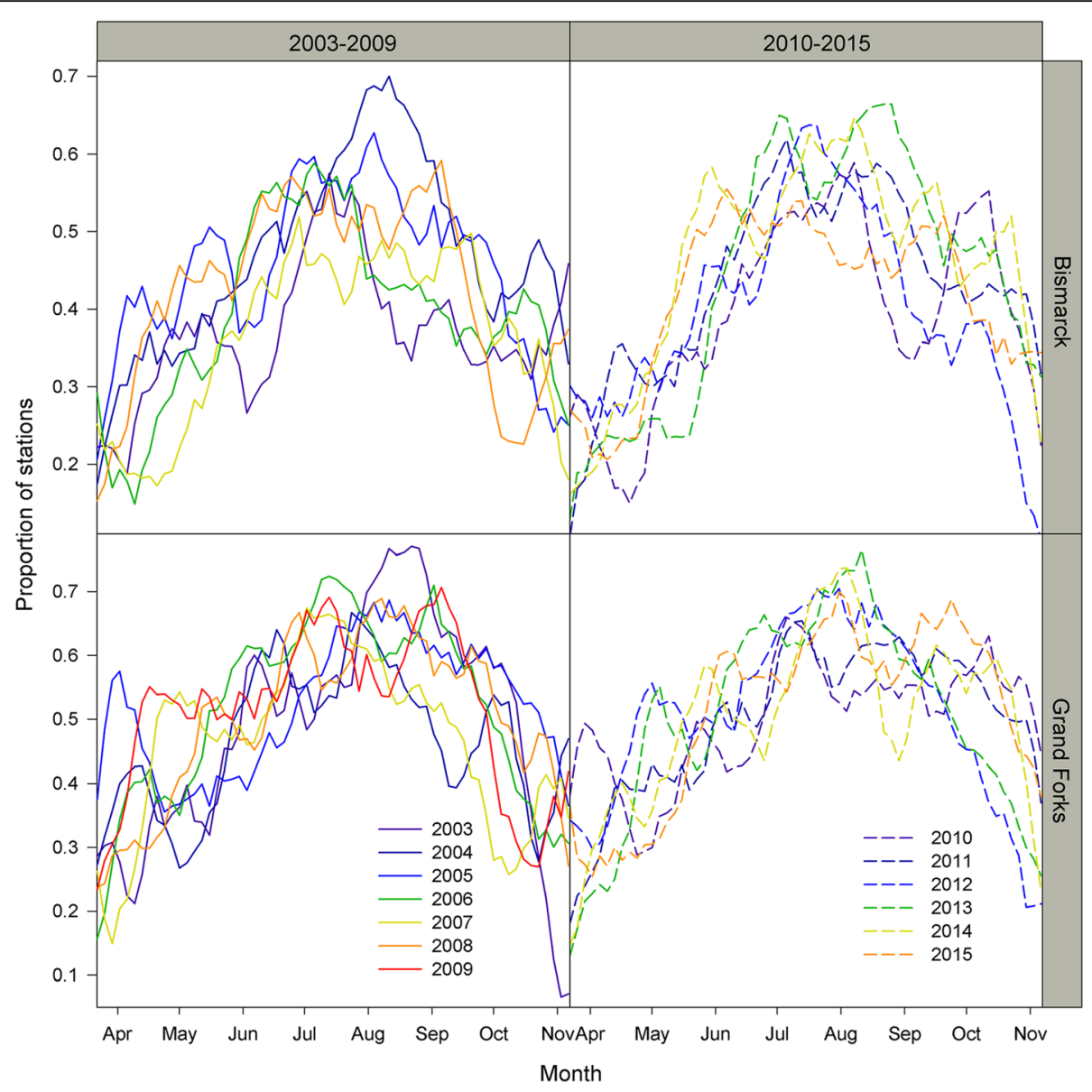

Fig. 3 Prescribed fire weather windows from early spring to late fall by year from 2003 to 2015 within the western Bismarck (top panels) and eastern Grand Forks (bottom panels) fire weather zones that cover North Dakota and Minnesota, USA (Fig. 1). For clarity, the first half of the years are shown in the left panels and the second half of the years are shown in the right panels. Lines are negative exponential smoothed averages of the daily proportion of stations with acceptable conditions over a running four-week period

These changes in the number of acceptable days reflect shifts in weather conditions during the daily 800 to $1800 \mathrm{~h}$ timeframe within the zones (Additional files 2, 3, 4, 5 and 6). Air temperatures fell below our query parameters in early spring and late fall (Additional file 2) and the extent to which air temperatures limited the number of acceptable days shifted over time. More days fell below the minimum operating temperature in early spring during the latter half of our study period (Additional file 2). This shift resulted in a decrease in the proportion of days that met air temperature (zone $F_{2,92.8}=20.82, P<0.0001$; year $F_{1,94.9}=30.89, P<0.0001$; $\mathrm{Z} \times \mathrm{Y} P<0.10$; Additional file 7) query conditions. Likewise, the extent to which wind limited the number of acceptable days also increased over time (zone $F_{2,49.4}$ $=5.53, P<0.01$; year $F_{1,50.8}=8.51, P<0.01 ; \mathrm{Z} \times \mathrm{Y} P$ $<0.10$; Additional file 7) as conditions became windier across the entire region in the latter half of the study timeframe (Additional file 3). The proportion of days without precipitation declined in the western, but not the eastern part of the study region (zone $F_{2,57.8}=5.25$, $P<0.01$; year $F_{1,59.8}=6.23, P<0.05 ; \mathrm{Y} \times \mathrm{Z} F_{1,59.8}=6.15$, $P<0.05$, Additional files 4 and 7). The extent to which relative humidity limited the number of acceptable days did not change over time (all terms $P<0.10$; Additional file 5).

Our multivariate analysis focused on assessing conditions within the acceptable daily windows. Weather and fuel conditions during acceptable daily fire weather windows showed distinct patterns among half-seasons, but were consistent through time and between fire weather zones (Fig. 5). The ordination identified two main axes (eigenvalues $>1.00$ ) of variation in weather and fuel conditions, which cumulatively explained $73 \%$ of variation in the dataset (axis 3 eigenvalue $=0.89,18 \%$ variation). Notably, variable loadings along these axes grouped according to how dynamic they are in a season. Variable loadings along the first principal component (eigenvalue $=2.30,46 \%$ variation) were highest for the seasonal weather variables dew point (3.3), air temperature 


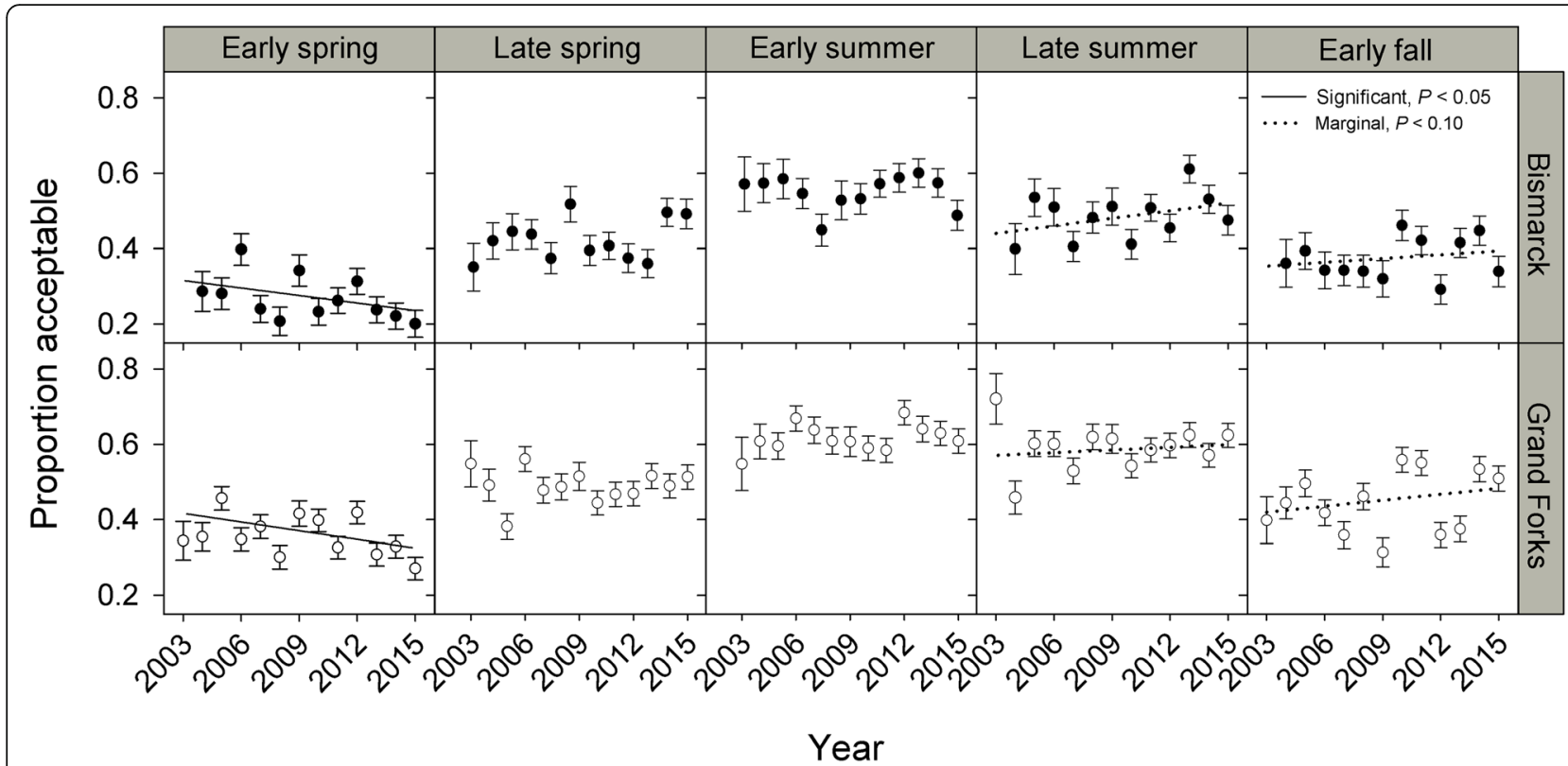

Fig. 4 Trend over time in the proportion of acceptable fire weather days ( $\pm 1 \mathrm{SE}$ ) that fell within each half-season in the western Bismarck (top panels) and eastern Grand Forks fire weather zones that cover North Dakota and Minnesota, USA (bottom panels; see Table 1 for date ranges). Lines indicate linear year effects (solid $=$ significant, $P<0.05$; dashed $=$ marginal, $P<0.10$ ) in each half-season

(3.1), and, to a lesser extent, relative humidity (1.8). Variation along the second principal component (eigenvalue $=1.34,27 \%$ variation) was most strongly associated with daily fire weather variables fuel moisture $(-3.0)$, wind speed $(-2.1)$, and relative humidity (0.9). From the permutation analyses, the half-season factor was the only factor significantly correlated with variation in the ordination $\left(P<0.001, \mathrm{R}^{2}=0.49\right.$; zone and year $P>0.99)$. Each half-season cluster was significantly different from every other cluster $(P<0.01)$ in pairwise permutation MANOVA comparisons.

In the fire behavior simulations, fire spread rate was most sensitive to wind speed and live fuel moisture conditions (Fig. 6). Fire spread was consistently greatest when simulated within the upper bounds of acceptable wind speed and lower bounds of acceptable fine dead fuel moisture during the acceptable fire weather windows. Fire spread rates were highest in well-cured fuels and in high-statured fuels $(60 \mathrm{~cm}$ ) with a lower live component (5 to 66\% through the fire season; low-statured $P$. pratensis scenario). Finally, fire spread was greatest in early spring and early fall. Collectively, the greatest fire spread rates $\left(>160 \mathrm{~m} \mathrm{~min}^{-1}\right)$ occurred when we simulated fire behavior within the more extreme weather conditions in low-statured $P$. pratensis and well-cured fuels in spring and fall. In contrast, the lowest spread rates $\left(<12 \mathrm{~m} \mathrm{~min}^{-1}\right)$ occurred when we simulated fire behavior in well-cured fuels with higher fine dead fuel moisture and at lower wind speeds, irrespective of the fuel invasion status and season. These rates of spread were consistent with maximal and minimal rates of spread associated with prescribed fires across the region (M. Zopfi, University of North Dakota, Grand Forks, North Dakota, USA, unpublished data).

\section{Discussion}

As climate change affects grasslands worldwide, there is a need to characterize prescribed fire seasons and how opportunities to use prescribed fire are changing (Huffman 2014, Chiodi et al. 2018). This is especially important to consider in the northern Great Plains as prescribed fire is important for invasive species control (Grant et al. 2009). From 2003 to 2015, the annual window for conducting prescribed fires across the northern Great Plains of the USA shifted from early spring to late fall. While daily weather conditions between 0800 and $1800 \mathrm{~h}$ were dynamic across years, our query parameters used to define acceptable weather days were similar across time, so it is not surprising that there was no year effect on conditions within daily acceptable fire windows. That said, there were substantial differences in fire weather and fuel conditions among half-seasons that could affect fire behavior. Seasonal effects on fire behavior were largest when prescribed fires were simulated at the upper bounds of acceptable wind speed and lower bounds of acceptable fuel moisture conditions.

Part of planning for prescribed fire involves understanding when fire can be applied in a year, and over what geographic area it can be applied to mobilize often limited resources during appropriate timeframes. In North Dakota and northeastern Minnesota, USA, 


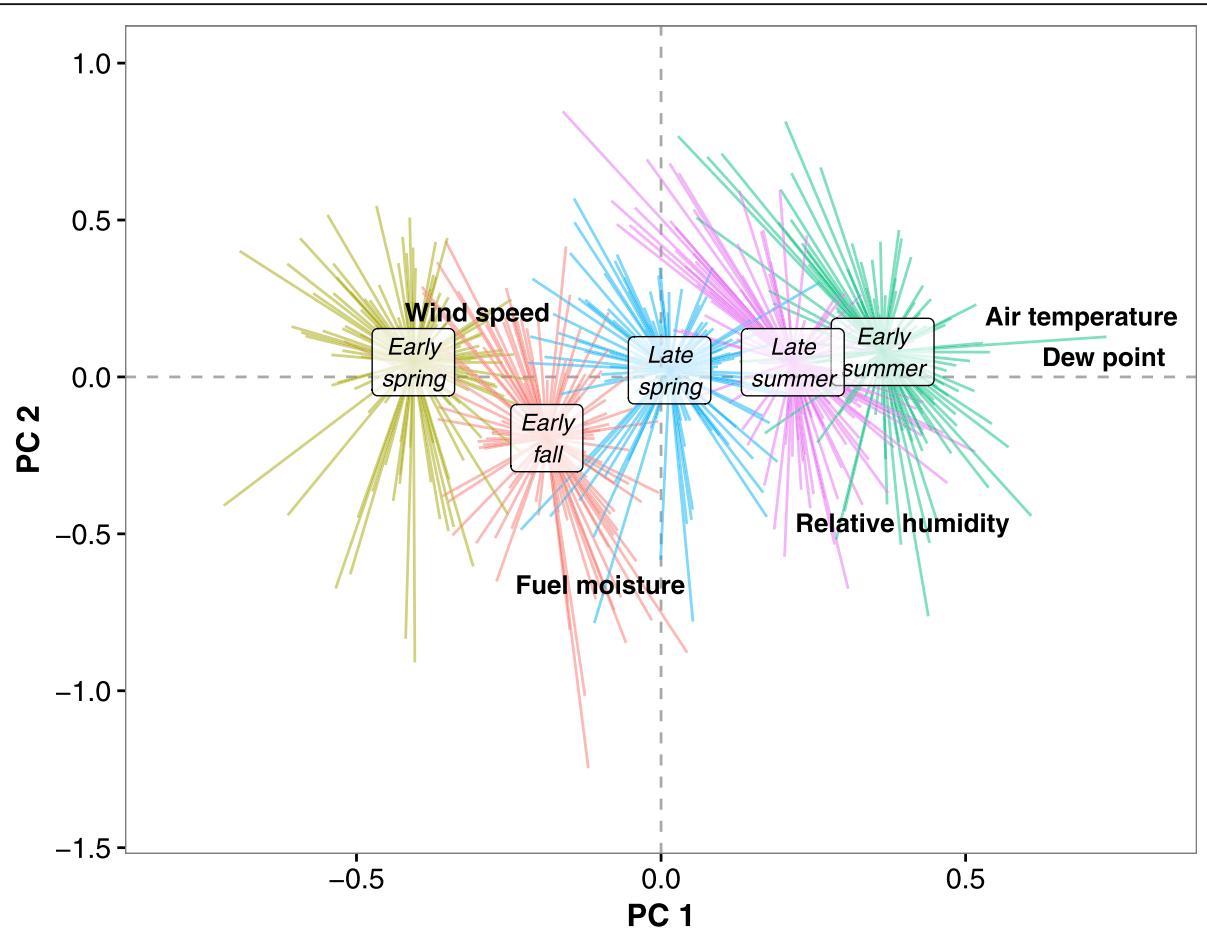

Fig. 5 Unconstrained Principal Components (PC) Analysis ordination of average fire weather and fuel moisture conditions within acceptable fire weather windows from 2005 to 2015 for 20 remote automated weather stations in the Bismarck and Grand Forks fire weather zones that span North Dakota and Minnesota, USA (Fig. 1). Weather and fuel moisture conditions within acceptable daily fire weather windows were averaged across five half-season periods (dates listed in Table 3) in each year for each station (645 data rows total). Lines connect each half-season observation to its respective half-season group centroids. Weather and fuel variables are shown in bold text positioned with respect to their loadings on the first (PC1) and second (PC2) principal component axes

managers must consider sites in the eastern portion of the region separately from those in the western portion. An east to west precipitation gradient exists within the northern Great Plains (Bunkers et al. 1996a) that affects vegetation productivity (Seager et al. 2018b), and it is not surprising that the two USA National Weather Service Fire Weather Zones in the region have distinct prescribed fire weather seasons. The more arid western portion of the region had a shorter average season with greater geographic variability than the wetter eastern portion of the region. This difference reflects unique seasonal climate conditions in each zone (Bunkers et al. 1996a, Badh et al. 2009), which may be moderated between zones in the future as the boundary between the more arid and more humid areas of the region moves eastward with climate change (Seager et al. 2018a, b).

While there was a geographic difference in length of prescribed fire season, we did not find any trend in the total length of the fire season from 2003 to 2015. We turn to growing season data, which closely parallels the prescribed fire season, to understand how this result fits in with longer-term climatic patterns in the region. It is well established that the growing season, commonly characterized by the period between the last spring frost and first fall frost, has increased in length in the northern Great
Plains (Skaggs and Baker 1985, Badh et al. 2009, Dunnell and Travers 2011) over the last century. Current climate models predict that the growing season length will continue to increase into the future (Christiansen et al. 2011, Kunkel et al. 2013). Although our study timeframe was too short to capture these long-term trends, we presume that fire weather windows would follow similar long-term and future trends.

While our study timeframe was limited in comparison to those that have assessed long-term regional climate trends, it is a valuable timeframe in which to characterize when fire can be applied and how that shifts over management time-scales. The annual prescribed fire weather window in both zones peaked midsummer and shifted from 2003 to 2015 . The number of days for early spring (21 March to 5 May) fires declined throughout the study area and the number of days for fall fires increased most prominently in the western zone. Our finding that the number of acceptable days in early spring was fewer as a result of more, colder days and as a result of unfavorable wind conditions March to early May is challenging to interpret against the rather limited literature for the region. We know that the first frost date of overnight low occurs in mid to late April and is later each year (Skaggs and Baker 1985, Badh et al. 2009, Dunnell and Travers 


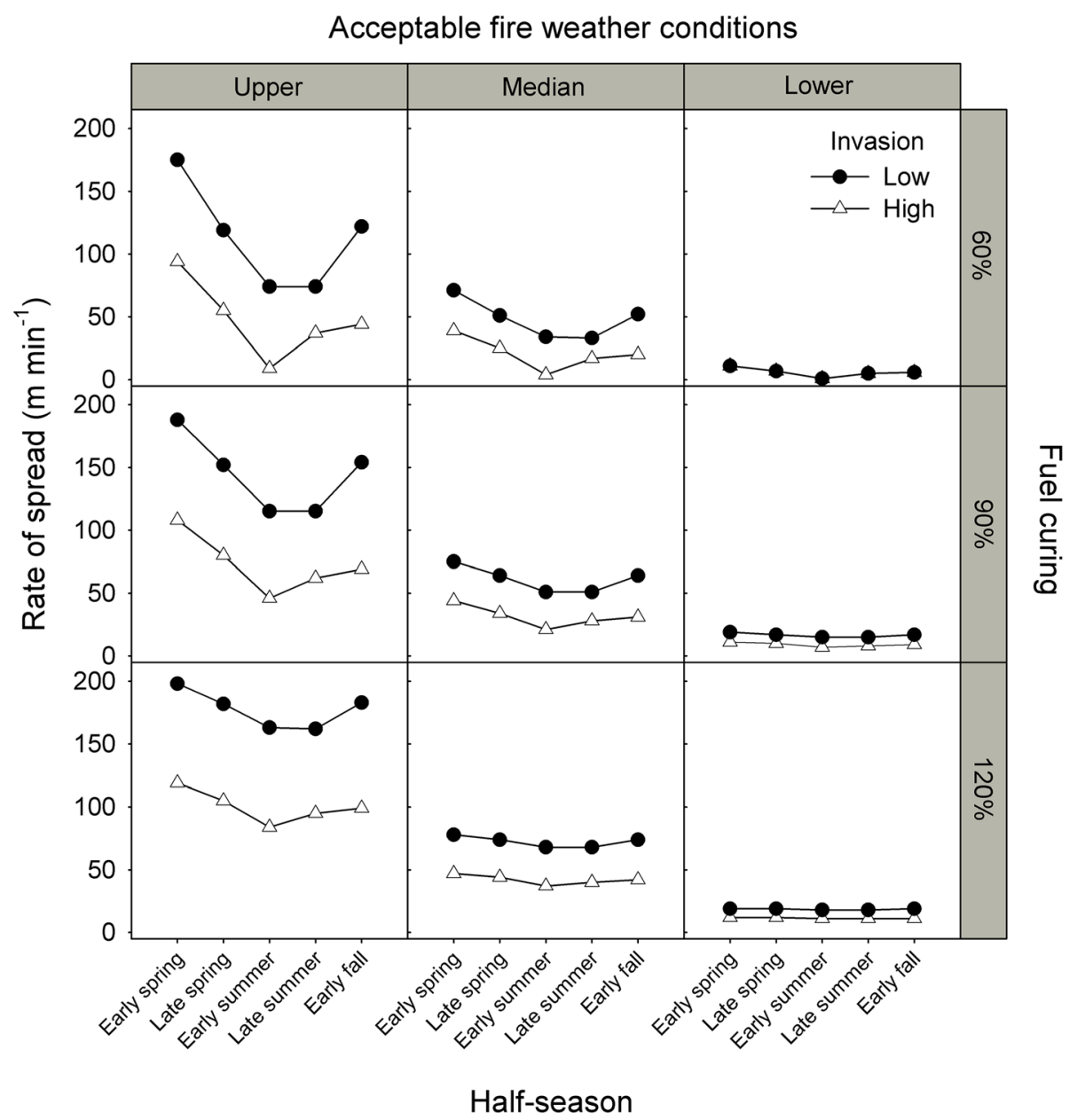

Fig. 6 Simulated fire spread for northern mixed-grass prairie under two levels of $P$. pratensis-invasion, three levels of live fuel curing, and three fire weather conditions for five half-season periods (dates listed in Table 3). Fire weather conditions were defined as the median and upper and lower bounds of acceptable prescribed fire weather (Table 2; see text for details) from 2003 to 2015 across the Bismarck and Grand Forks fire weather zones that cover North Dakota and Minnesota, USA (Fig. 1)

2011). However, Dunnell and Travers (2011) found that monthly February and May, but not March and April, mean air temperatures have increased in the eastern portion of the study area over the last hundred years, suggesting that warming has not been consistent over the spring months and supporting our finding that temperatures may in fact be declining during portions of the year. As Skaggs and Baker (1985) discussed, this all points to the need to understand weather conditions specific to the question at hand and the relative difficulty in connecting mean climatic changes and projections, which are often presented on an annual or seasonal basis at best (Kunkel et al. 2013), with functional changes in ecosystems.

To address to what extent shifting fire weather windows have affected fuel conditions (Clark et al. 2008, Liu et al. 2015) and the outcomes of prescribed fire management, we assessed weather and fuel conditions during the acceptable windows. Acceptable burn days in different half-seasons and across both zones had unique sets of conditions. Broadly speaking, conditions on acceptable burn days fell into three categories: dormant season (early spring, early fall), early growing season (late spring, early summer), and late growing season (late summer). Variation from half-season to half-season was driven by seasonal temperature and atmospheric moisture variables; specifically, average air temperature and dew point. Within season, variation among acceptable burn days was associated with fuel moisture, relative humidity, and wind speed.

Fire behavior determines the extent to which prescribed fire consumes accumulated litter (Dix 1960) and reaches plant-fatal temperatures (Grace et al. 2001, Vermeire et al. 2011), and is largely determined by weather and fuel conditions (Clark et al. 2008, Liu et al. 2015). Fire behavior simulations for the region suggest seasonal differences in rate of spread. When prescribed fires were simulated in the upper end of acceptable wind speed and fuel moisture 
conditions, spread rates varied with invasion extent, fine fuel moisture content, and season. When fires were simulated in the mid range of acceptable conditions, season and, to a lesser extent, invasion and curing affected spread. When fires occurred at the lowest acceptable conditions, rate of spread was an order of magnitude lower than other fire weather scenarios, and thus similarly low across seasons, invasion status, and fuel curing. Most substantially, late summer fires are expected to have very low rates of spread on account of high proportions of live herbaceous fuels. High proportions of the cool season invasive grass Poa pratensis reduces predicted fire spread in all seasons, but is partially mitigated by high levels of live fuel curing (60\% live fuel moisture) and weather conditions at the upper bound of the acceptable burn window. Furthermore, changes in site species composition with the invasion of non-native plant species may require changing the burning window to accommodate different fuel loads within invaded sites (McGranahan et al. 2012).

These results have management implications for the region. Even though there is a general ecological and operational interest in growing season fire (Engle and Bidwell 2001) and our data suggest that burn day availability is shifting towards the summer in the northern Great Plains, this is also the period of the year least conducive to fire spread, especially in the invaded grasslands that need fire the most. Getting fire to spread in the growing season requires days with the high wind speed and low moisture conditions that are more likely to earn a burn ban. From a seasonal standpoint, late spring and early fall can be depended upon for good prescribed fire weather, but opportunity exists to use prescribed fire throughout the summer months. Many management protocols call for spring fires in order to control Poa pratensis and Bromus inermis (Towne and Owensby 1984, Gibson et al. 1993, Salesman and Thomsen 1993, Grace et al. 2001, Willson 2000). However, because fires have low direct kill rates (Clarke et al. 1943, Ramsay and Oxley 1996, Grace et al. 2001), it may be more worthwhile to take advantage of any season for burning in order to control thatch accumulation (Towne and Owensby 1984, Engle and Bidwell 2001).

Finally, although conditions exist to support season-long prescribed fire in the northern Great Plains, we need to address the human dimensions of prescribed fire management in the region (Toledo et al. 2013). Cessation of fire has affected vegetation composition and wildlife use of grasslands throughout the study area (Kirsch and Kruse 1973) and beyond. In order to maintain grassland integrity globally, we need a focused effort to characterize and address how human perceptions of fire and the effects of prescribed fire management are affecting human prescribed fire management decisions (Gobster et al. 2016, Hurst et al. 2017), including decisions surrounding the seasonality, frequency, and intensity of prescribed fire management.
Studies that detail potential prescribed fire opportunities (Weir 2011, Chiodi et al. 2018) can help fire and fuels managers plan and organize needed resources for conducting safe and effective prescribed fires.

\section{Conclusions}

Opportunities exist for conducting prescribed fire in the northern Great Plains throughout the growing season. Over a recent 11-year period, windows for applying prescribed fire shifted from the spring to the fall. As fire and fuels managers plan for land management on existing and new sites in the region, their plans need to incorporate and be responsive to these and future changes in number of acceptable days within different fire seasons. While such adaptive management is commonplace for more seasoned grassland managers, this is an important consideration in regions for which the use of prescribed fire is expanding and for which non-traditional and novice stakeholders are involved in decision making. Notably, rigid prescriptions calling for a particular season may be less useful for meeting management goals than those that plan for and accommodate shifting prescribed fire seasons.

\section{Additional files}

\begin{abstract}
Additional file 1: Acceptable prescribed fire days for each study weather station in the Bismarck (top panels) and Grand Forks (bottom panels) fire weather zones that cover North Dakota and Minnesota, USA (Fig. 1). Zone data are summarized by year (right axis; grey points). Each line of grey points in each year indicates days that were acceptable for prescribed fire for a single station. For clarity, the first half of the years are shown in the left panels and the second half of the years are shown in the right panels. Solid lines (left axis) indicate the proportion of station-years with acceptable conditions during the fire season from 2003 to 2009 and 2010 to 2015. (PDF $740 \mathrm{~kb}$ )

Additional file 2: Average daily air temperature (points) during a 10-h (0800 to 1800 h) window for each study weather station in the Bismarck (top panels) and Grand Forks (bottom panels) fire weather zones that cover North Dakota and Minnesota, USA (Fig. 1). For clarity, data for the first half of the study years are shown in the left panels and the second half of the years are shown in the right panels. Solid lines indicate the average daily 10 -h air temperature across station-years during the fire season for first half (2003 to 2009; left panels) and the second half (2010 to 2015; right panels) of the study period. Days were deemed acceptable for prescribed fire when air temperatures exceeded $2{ }^{\circ} \mathrm{C}$ (solid horizontal line) for a minimum six-hour period in the 0800 to $1800 \mathrm{~h}$ window. (PDF $401 \mathrm{~kb}$ )
\end{abstract}

Additional file 3: Average wind speed (points) during a 10-h (0800 to $1800 \mathrm{~h}$ ) window for each study weather station in the Bismarck (top panels) and Grand Forks (bottom panels) fire weather zones that cover North Dakota and Minnesota, USA (Fig. 1). For clarity, data for the first half of the study years are shown in the left panels and the second half of the years are shown in the right panels. Solid lines indicate the average daily 10-h wind speeds across station-years during the fire season for first half (2003 to 2009; left panels) and the second half (2010 to 2015; right panels) of the study period. Days were deemed acceptable for prescribed fire when the sustained wind speed averaged between $6.44 \mathrm{~km} \mathrm{~h}^{-1}$ and $24.14 \mathrm{~km} \mathrm{~h}^{-1}$ (4 mph and $15 \mathrm{mph}$; solid horizontal lines). (PDF $417 \mathrm{~kb}$ )

Additional file 4: Precipitation recorded (points; log-scale) during a 10-h (0800 to 1800 h) window for each study weather station in the Bismarck (top panels) and Grand Forks (bottom panels) fire weather zones that 
cover North Dakota and Minnesota, USA (Fig. 1). For clarity, data for the first half of the study years are shown in the left panels and the second half of the years are shown in the right panels. Solid lines indicate the average daily 10-h precipitation across station-years during the fire season for first half (2003 to 2009; left panels) and the second half (2010 to2015: right panels) of the study period. (PDF $555 \mathrm{~kb}$ )

Additional file 5: Average percent relative humidity (points) during a 10-h (0800 to 1800 h) window for each study weather station in the Bismarck (top panels) and Grand Forks (bottom panels) fire weather zones that cover North Dakota and Minnesota, USA (Fig. 1). For clarity, data for the first half of the study years are shown in the left panels and the second half of the years are shown in the right panels. Solid lines indicate the average daily $10-h$ wind speeds across station-years during the fire season for first half (2003 to 2009; left panels) and the second half (2010 to 2015; right panels) of the study period. Days were considered acceptable for prescribed fire when the relative humidity averaged between $25 \%$ and $80 \%$ (solid horizontal lines). (PDF $657 \mathrm{~kb}$ )

Additional file 6: Average dew point $\left({ }^{\circ} \mathrm{C}\right)$ during a 10-h (0800 to 1800 h) window for each study weather station in the Bismarck (top panels) and Grand Forks (bottom panels) fire weather zones that cover North Dakota and Minnesota, USA (Fig. 1). For clarity, data for the first half of the study years are shown in the left panels and the second half of the years are shown in the right panels. Solid lines indicate the average daily ten-hour wind speeds across station-years during the fire season for first half (2003 to 2009; left panels) and the second half (2010 to 2015; right panels) of the study period (PDF $407 \mathrm{~kb}$ )

Additional file 7: Proportion of early spring days from 2003 to 2015 ( $\pm 1 \mathrm{SE}$ ) that fell within the air temperature, precipitation, and wind query limits for the western Bismarck (top panels) and eastern Grand Forks (bottom panels) fire weather zones that cover North Dakota and Minnesota, USA (Fig. 1). Lines indicate linear year effects. See Additional files 1, 2, 3, 4, 5 and 6 for actual conditions recorded. (PDF $141 \mathrm{~kb}$ )

\section{Acknowledgements}

Conversations with Isaac Schlosser and personnel from Badger Creek Wildfire (Poplar, Montana, USA) surrounding implementing a novel prescribed fire program on University of North Dakota's Oakville Prairie prompted this wider consideration of when and to what extent we can consistently use prescribed fire in the region.

\section{Funding}

This project was supported by a University of North Dakota College of Arts and Sciences Applied Research to Address the State's Critical Needs Grant and by funding from a North Dakota Game and Fish Department State Wildlife Grant.

\section{Availability of data and materials}

The datasets analyzed for this study are available in the University of Utah MesoWest repository, https://mesowest.utah.edu/. The reduced dataset used and analyzed during the current study is available from the corresponding author on reasonable request.

\section{Authors' contributions}

K.A. Yurkonis and B.J. Goodwin conceived the study, J. Dillon assisted with data acquisition and processing, K.A. Yurkonis conducted the data analysis and prepared the manuscript with assistance from D. Toledo and D.A. McGranahan. All authors read and approved the final manuscript.

\section{Ethics approval and consent to participate} Not applicable.

\section{Consent for publication}

Not applicable.

\section{Competing interests}

The authors declare that they have no competing interests.

\section{Publisher's Note}

Springer Nature remains neutral with regard to jurisdictional claims in published maps and institutional affiliations.

\section{Author details}

'Department of Biology, University of North Dakota, 10 Cornell Street, Stop 9019, Grand Forks, North Dakota 58202, USA. ²Range Science Program, School of Natural Resources, North Dakota State University, PO Box 7650, Fargo, North Dakota 58108, USA. ${ }^{3}$ USDA-ARS Northern Great Plains Research Laboratory, 1701 10th Avenue SW, Mandan, North Dakota 58554, USA. ${ }^{4}$ School of Environmental and Natural Resources Sciences, Frost Campus, Fleming College, 200 Albert Street S, Lindsay, Ontario K9V 5E6, Canada.

Received: 11 July 2018 Accepted: 25 January 2019

Published online: 25 March 2019

\section{References}

Badh, A., A. Akyuz, G. Vocke, and B. Mullins. 2009. Impact of climate change on the growing seasons in select cities of North Dakota, United States of America. International Journal of Climate Cjhange: Impacts and Responses 1: 105-118. https://doi.org/10.18848/1835-7156/CGP/v01i01/37130.

Bahm, M.A., T.G. Barnes, and K.C. Jensen. 2011. Herbicide and fire effects on smooth brome (Bromus inermis) and Kentucky bluegrass (Poa pratensis) in invaded prairie remnants. Invasive Plant Science and Management 4: 189-197. https://doi.org/10.1614/IPSM-D-10-00046.1.

Bierbaum, R., J.B. Smith, A. Lee, M. Blair, L. Carter, S. Chapin III, P. Fleming, S. Ruffo, M. Stults, S. McNeeley, E. Wasley, and L. Verduzco. 2013. A comprehensive review of climate adaptation in the United States: more than before, but less than needed. Mitigation and Adaptation Strategies for Global Change 18: 361-406. https://doi.org/10.1007/s11027-012-9423-1.

Biondini, M.E., A.A. Steuter, and C.E. Grygiel. 1989. Seasonal fire effects on the diversity patterns, spatial distribution and community structure of forbs in the Northern Mixed Prairie, USA. Vegetatio 85: 21-31. https://doi.org/10.1007/ BF00042252.

Brown, T.J., B.L. Hall, and A.L. Westerling. 2004. The impact of twenty-first century climate change on wildland fire danger in the western United States: an applications perspective. Climatic Change 62: 365-388. https://doi.org/10. 1023/B:CLIM.0000013680.07783.de.

Bunkers, M.J., J.R. Miller, and A.T. DeGaetano. 1996a. Definition of climate regions in the Northern Plains using an objective cluster modification technique. Journal of Climate 9: 130-146. https://doi.org/10.1175/15200442(1996)009\%3C0130:DOCRIT\%3E2.0.CO:2.

Bunkers, M.J., J.R. Miller, and A.T. DeGaetano. 1996b. An examination of El Niño-La Niña-related precipitation and temperature anomalies across the Northern Plains. Journal of Climate 9: 147-160. https://doi.org/10.1175/ 1520-0442(1996)009\%3C0147:AEOENN\%3E2.0.CO;2.

Chiodi, A.M., N.S. Larkin, and J.M. Varner. 2018. An analysis of southeastern US prescribed burn weather windows: seasonal variability and El Niño associations. International Journal of Wildland Fire 27: 176-189. https://doi.org/10.1071/WF17132.

Christiansen, D.E., S.L. Markstrom, and L.E. Hay. 2011. Impacts of climate change on the growing season in the United States. Earth Interactions 15: 1-17. https://doi.org/10.1175/2011El376.1.

Ciuti, S., W.F. Jensen, S.E. Nielsen, and M.S. Boyce. 2015. Predicting mule deer recruitment from climate oscillations for harvest management on the northern Great Plains. Journal of Wildlife Management 79: 1226-1238. https://doi.org/10.1002/jwmg.956.

Clark, R.E., A.S. Hope, S. Tarantola, D. Gatelli, P.E. Dennison, and M.A. Moritz. 2008. Sensitivity analysis of a fire spread model in a chaparral landscape. Fire Ecology 4 (1): 1-13. https://doi.org/10.4996/fireecology.0401001.

Clarke, S.E., E.W. Tisdale, and N.A. Skoglund. 1943. The effects of climate and grazing practices on short-grass prairie vegetation in southern Alberta and southwestern Saskatchewan. Ottawa: Canada Deptartment of Agriculture.

Dix, R.L. 1960. The effects of burning on the mulch structure and species composition of grasslands in western North Dakota. Ecology 41: 49-56. https://doi.org/10.2307/1931938

Dunnell, K.L., and S.E. Travers. 2011. Shifts in the flowering phenology of the northern Great Plains: patterns over 100 years. American Journal of Botany 98: 935-945. https://doi.org/10.3732/ajb.1000363.

Easterling, D.R. 2002. Recent changes in frost days and the frost-free season in the United States. Bulletin of the American Meteorological Society 83 (9): 1327-1332. https://doi.org/10.1175/1520-0477-83.9.1327. 
Easterling, D.R., B. Horton, P.D. Jones, T.C. Peterson, T.R. Karl, D.E. Parker, M.J. Salinger, V. Razuvayev, N. Plummer, P.I Jamason, and C.K. Folland. 1997. Maximum and minimum temperature trends for the globe. Science 277: 364367. doi: https://doi.org/10.1126/science.277.5324.364.

Engle, D.M., and T.G. Bidwell. 2001. Viewpoint: the response of central North American prairies to seasonal fire. Journal of Range Management 54: 2-10. https://doi.org/10.2307/4003519.

Gibson, D.J., T.R. Seastedt, and J.M. Briggs. 1993. Management practices in tallgrass prairie: large- and small-scale experimental effects on species composition. Journal of Applied Ecology 30: 247-255. https://doi.org/10.2307/2404626.

Gobster, P.H., K. Floress, L.M. Westphal, C.A. Watkins, J. Vining, and A. Wali. 2016. Resident and user support for urban natural areas restoration practices. Biological Conservation 203: 216-225. https://doi.org/10.1016/j.biocon.2016.09.025.

Grace, J.B., M.D. Smith, S.L. Grace, S.L. Collins, and TJ Stohlgren. 2001. Interactions between fire and invasive plants in temperate grasslands of North America. Pages 40-65 in: K. Galley and T. Wilson, editors. Proceedings of the invasive species workshop: the role of fire in the control and spread of invasive species. Tall Timbers Research Station, Miscellaneous Publication 11, Tallahassee, Florida, USA.

Grant, T.A., B. Flanders-Wanner, T.L. Shaffer, R.K. Murphy, and G.A. Knutsen. 2009. An emerging crisis across northern prairie refuges: prevalence of invasive plants and a plan for adaptive management. Ecological Restoration 27: 58-65. https://doi.org/10.3368/er.27.1.58.

Hervé, M. 2018. RVAideMemoire: testing and plotting procedures for biostatistics. $R$ package version 0.9-68. <https://CRAN.R-project.org/package=RVAideMemoire> Accessed 15 Aug 2018.

Hoerling, M., J. Eischeid, A. Kumar, R. Leung, A. Mariotti, K. Mo, S. Schubert, and R. Seager. 2014. Causes and predictability of the 2012 Great Plains drought. Bulletin of the American Meteorological Society 95: 269-282. https://doi.org/10. 1175/BAMS-D-13-00055.1.

Huffman, M.R. 2014. Making a world of difference in fire and climate change. Fire Ecology 10 (3): 90-101. https://doi.org/10.4996/fireecology.1003090.

Hurst, K.F., C.P. Ramsdell, and M.G. Sorice. 2017. A life course approach to understanding social drivers of rangeland conversion. Ecology and Society 22 (1): 19. https://doi.org/10.5751/ES-08990-220119.

Karl, T.R., R.W. Knight, D.R. Easterling, and R.G. Quayle. 1996. Indices of climate change for the United States. Bulletin of the American Meteorological Society 77: 279-292. https://doi.org/10.1175/1520-0477(1996)077\%3C0279:IOCCFT\%3E2.0.CO;2.

Kirsch, L.M., and A.D. Kruse. 1973. Prairie fires and wildlife. Proceedings of the Tall Timbers Fire Ecology Conference 12: 289-303.

Kunkel, K.E., L.E. Stevens, S.E. Stevens, L. Sun, E. Janssen, D. Wuebbles, K.T. Redmond, and J.G. Dobson. 2013. Regional climate trends and scenarios for the US national climate assessment part 4: climate of the US Great Plains. US National Oceanic and Atmospheric Administration, Washington, D.C. In USA.

Liu, Y., M.Y. Hussaini, and G. Ökten. 2015. Global sensitivity analysis for the Rothermel model based on high-dimensional model representation. Canadian Journal of Forest Research 45: 1474-1479. https://doi.org/10.1139/cjfr-2015-0148.

McGranahan, D.A., S. Archibald, K.P. Kirkman, and T.G. O'Connor. 2018. A native $C_{3}$ grass alters fuels and fire spread in montane grassland of South Africa. Plant Ecology 219: 621-632. https://doi.org/10.1007/s11258-018-0822-6.

McGranahan, D.A., D.M. Engle, S.D. Fuhlendorf, J.R. Miller, and D.M. Debinski. 2012. An invasive cool-season grass complicates prescribed fire management in a native warm-season grassland. Natural Areas Journal 32 (2): 208-214. https:// doi.org/10.3375/043.032.0214

McGranahan, D.A., D.M. Engle, J.R. Miller, and D.M. Debinski. 2013. An invasive grass increases live fuel proportion and reduces fire spread in a simulated grassland. Ecosystems 16: 158-169. https://doi.org/10.1007/s10021-012-9605-4.

McGranahan, D.A., R. Ramaano, M.J. Tedder, and K.P. Kirkman. 2016. Variation in grassland fuel curing in South Africa. Fire Ecology 12: 40-52. https://doi.org/ 10.4996/fireecology.1203040. doi: https://doi.org/10.4996/fireecology.1203040

Melillo, J.M., T. Richmond, and G. Yohe. 2014. Climate change impacts in the United States: the third national climate assessment. Washington, D.C: US Global Change Research Program. https://doi.org/10.7930/J0Z31WJ2.

Mushet, D.M., M.B. Goldhaber, C.T. Mills, K.I. McLean, V.M. Aparicio, R.B. McCleskey, J.M. Holloway, and C.A. Stockwell. 2015. Chemical and biotic characteristics of prairie lakes and large wetlands in south-central North Dakota-effects of a changing climate. US Geological Survey Scientific Investigations Report 2015-5126, Reston, Virginia, USA. https://doi.org/10.3133/sir20155126

Oksanen, J., F.G. Blanchet, M. Friendly, R. Kindt, P. Legendre, D. McGlinn, P.R. Minchin, R.B. O'Hara, G.L. Simpson, P. Solymos, M. Henry, H. Stevens, E. Szoecs, and H. Wagner. (2017) vegan: community ecology package. R package, version 2.5-3. <https://cran.r-project.org/web/packages/vegan/ index.html>. Accessed 15 Aug 2018.

R Core Team. 2017. R: a language and environment for statistical computing Vienna: R Foundation for Statistical Computing.

Ramsay, P.M., and E.R.B. Oxley. 1996. Fire temperatures and postfire plant community dynamics in Ecuadorian grass paramo. Vegetatio 124: 129-144.

Romsdahl, R.J., L. Atkinson, and J. Schultz. 2013. Planning for climate change across the US Great Plains: concerns and insights from government decisionmakers. Journal of Environmental Studies and Sciences 3: 1-14. https://doi.org/ 10.1007/s13412-012-0078-8.

Rothermel, R.C. 1972. A mathematical model for predicting fire spread in wildland fuels. US Department of Agriculture Research Paper INT-115, Intermountain Forest and Range Experiment Station, Ogden, Utah. In USA.

Roundy, J., and J. Santanello. 2017. The impact of land-atmosphere coupling on the 2017 Northern Great Plains drought. Presented at American Geophysical Union Fall 2017 Meeting, 11-15 December 2017, New Orleans, Louisiana, USA.

Russell, M.L., L.T. Vermeire, A.C. Ganguli, and J.R. Hendrickson. 2015. Season of fire manipulates bud bank dynamics in northern mixed-grass prairie. Plant Ecology 216: 835-846. https://doi.org/10.1007/s11258-015-0471-y.

Salesman, J.B., and M. Thomsen. 1993. Smooth brome (Bromus inermis) in tallgrass prairies: a review of control methods and future research directions. Ecological Restoration 29: 374-381. https://doi.org/10.3368/er.29.4.374.

Scott, J., and R. Burgan. 2005. Standard fire behavior fuel models: a comprehensive set for use with Rothermel's surface fire spread model. USA Forest Service, General Technical Report RMRSGTR-153, Rocky Mountain Research Station, Fort Collins, Colorado, USA. doi: https://doi.org/10.2737/ RMRS-GTR-153.

Seager, R., N. Lis, J. Feldman, M. Ting, A.P. Williams, J. Nakamura, H. Liu, and N. Henderson. 2018a. Whither the 100th meridian? The once and future physical and human geography of America's arid-humid divide. Part II: the meridian moves east. Earth Interactions 22: 1-24. https://doi.org/10.1175/El-D-17-0012.1.

Seager, R., N. Lis, J. Feldman, M. Ting, A.P. Williams, J. Nakamura, H. Liu, and N. Henderson. 2018b. Whither the 100th meridian? The once and future physical and human geography of America's arid-humid divide. Part I: the story so far. Earth Interactions 22: 1-22. doi: https://doi.org/10.1175/El-D-17-0011.1.

Shafer, M., D. Ojima, J.M. Antle, D. Kluck, R.A. McPherson, S. Petersen, B. Scanlon, and K. Sherman. 2014. Chapter 19: Great Plains. In Climate change impacts in the United States: the third national climate assessment, ed. J.M. Melillo, T. Richmond, and G. Yohe, 441-461. Washington, D.C.: US Global Change Research Program.

Skaggs, R.H., and D.G. Baker. 1985. Fluctuations in the length of the growing season in Minnesota. Climatic Change 7: 403-414. https://doi.org/10.1007/ BF00139055.

Toledo, D., M. Sanderson, K. Spaeth, J. Hendrickson, and J. Printz. 2014. Extent of Kentucky bluegrass and its effect on native plant species diversity and ecosystem services in the northern Great Plains of the United States. Invasive Plant Science and Management 7: 543-552. https://doi.org/10. 1614/IPSM-D-14-00029.1.

Toledo, D., M.G. Sorice, and U.P. Kreuter. 2013. Social and ecological factors influencing attitudes toward the application of high-intensity prescribed burns to restore fire adapted grassland ecosystems. Ecology and Society 18 (4): 9. https://doi.org/10.5751/ES-05820-180409.

Towne, G., and C. Owensby. 1984. Long-term effects of annual burning at different dates in ungrazed Kansas tallgrass prairie. Journal of Range Management 37: 392-397. https://doi.org/10.2307/3899622.

Vacchiano, G., and D. Ascoli. 2015. An implementation of the Rothermel fire spread model in the R programming language. Fire Technology 51: 523-535. https://doi.org/10.1007/s10694-014-0405-6.

Vermeire, L.T., J.L. Crowder, and D.B. Wester. 2011. Plant community and soil environment response to summer fire in the northern Great Plains. Journal of Range Management 64: 37-46. https://doi.org/10.2111/REM-D-10-00049.1.

Weir, J.R. 2011. Are weather and tradition reducing our ability to conduct prescribed burns? Rangelands 33: 25-30. https://doi.org/10.2111/ RANGELANDS-D-10-00050.1.

Werner, B.A., W.C. Johnson, and G.R. Guntenspergen. 2013. Evidence for 20th century climate warming and wetland drying in the North American Prairie Pothole Region. Ecology and Evololution 3: 3471-3482. https://doi.org/10. 1002/ece3.731.

Willson, G.D. 2000. A provisional model for smooth brome management in degraded tallgrass prairie. Ecological Restoration 18: 34-38. https://doi.org/10. 3368/er.18.1.34. 
Winter, T.C., and D.O. Rosenberry. 1998. Hydrology of prairie pothole wetlands during drought and deluge: a 17-year study of the Cottonwood Lake Wetland Complex in North Dakota in the perspective of longer term measured and proxy hydrological records. Climatic Change 40: 189-209. https://doi.org/10.1023/A:1005448416571.

Woodhouse, C.A., and J.T. Overpeck. 1998. 2000 years of drought variability in the central United States. Bulletin of the American Meteorological Society 79: 2693-2714. https://doi.org/10.1175/15200477(1998)079\%3C2693:YODVIT\%3E2.0.CO;2

Zachariassen, J., K.F. Zeller, N. Nikolov, and T. McClelland. 2003. A review of the Forest Service remote automated weather station (RAWS) network. USDA Forest Service General Technical Report RMRS-GTR-119, Rocky Mountain Research Station, Fort Collins.

Submit your manuscript to a SpringerOpen ${ }^{\mathcal{O}}$ journal and benefit from:

- Convenient online submission

- Rigorous peer review

- Open access: articles freely available online

- High visibility within the field

- Retaining the copyright to your article

Submit your next manuscript at $\boldsymbol{\nabla}$ springeropen.com 